\title{
The Coupling Mode Exploration of Innovative Entrepreneurship Education and Professional Education in Art Colleges
}

\author{
Liu Rong \\ Cultural Creation Teaching Center, Xi'an Academy of Fine Arts, Shaanxi, China, 710065
}

Keywords: Art College; Innovative Entrepreneurship Education; Professional Education; Coupling Mode

Abstract: In the knowledge economy era, the new challenges and requirements for the cultivation mode of higher education talents are proposed with the transformation from skill master to intelligent cultivation, from professional type to composite talents, from application to innovative talents. Art colleges are closely related to social and economic development in innovative talent cultivation and transformation of technological achievements, which has the unique advantage of carrying out innovative entrepreneurship education. This paper focuses on exploring the coupling of innovative entrepreneurship education and professional art education to achieve high-level innovative entrepreneurship education with art major as the core.

\section{The unique advantages of innovative entrepreneurship education in art colleges}

Compared with students of other basic colleges, the art college students are enthusiastic, who advocate personality and enriching imagination. Once their creative and innovative thinking is combined with modern technology, it is easy to create literature works full of the artistic atmosphere and the unique creation. It is easier to fully play the advantages of professional entrepreneurship. Whether it is from the major of art colleges or from the innovative entrepreneurship education, it is imperative to carry out innovative entrepreneurship education in the Academy of Fine Arts.

\subsection{Major commonality.}

From the commonality of art major itself, it has strong practicality and applicability, and students continuously realize the transformation of creative ideas and the creative thinking in the practical creation. Through the study of professional courses, the comprehensive abilities in aesthetic perception and innovative practice are enhanced, of which comprehensive qualities are the core of innovative entrepreneurship education.

\subsection{Features of painting major.}

From the painting major, students' creative works do not need the large-scale production and 
processing, and the cycle time of transformation of artistic works is short. Art entrepreneurship itself is also pursuing for beauty, expressing profession and creativity in the arts. From the initial creation to the fulfillment of the entrepreneurship projects, the speed is obviously higher than other industries, and the process of artists completing the work is also the process of achieving innovative entrepreneurship.

\subsection{Features of the design major.}

From the design profession, it has strong extension and applicability, including art fields of fashion design, public art, visual communication, industrial design, environmental art design, animation, film and photography. These majors are closely related to every aspect of people's clothes, food, housing and transportation. Art design students choose their own major advantages and achieve a high integration between art and design.

\subsection{Flexibility in employment option.}

From the perspective of the employment option of students in art colleges, they are more advocating freedom with more choice of the flexible employment by most students. When planning for future careers, unlike other college students who tend to be more stable, they pay more attention to the matching of profession with interest, and free and flexible careers. At the time of their campus life, most students start to engage in the entrepreneurship projects similar or related to the major. The self-employment rate at graduation is significantly higher than that of other profession students. They most are engaged in creative industries such as fashion design, graphic design, film and television animation, and literature and creative products.

\subsection{The easy-to-reach feature of art profession entrepreneurship.}

In recent years, the state and the government have vigorously supported the cultural and creative industries, which will bring new opportunities and challenges to the innovative entrepreneurship education of art college students. This will also enable the art college students to achieve artistic creativity and entrepreneurship. In the future, there will be more art students joining the army of cultural and creative industries.

\section{The combination of profession education and innovative entrepreneurship education in art colleges}

The deep combination of innovative entrepreneurship education with profession education in art colleges is the cut point for art college students suitable for market demand to carry out education and teaching reform. Art colleges are playing an increasingly important role in regional cultural construction and modern cultural industry development. The famous "Qian Xuesen's Question" also allows us to constantly consider the transformation of the functions and values of art schools. Only the innovative creation completed in the social economy is the most energetic, valuable and lasting innovative creation. After the entrepreneurship economy shows, art colleges must not only strengthen their social service performances, but more importantly, promote the transformation of university functions through social services, from traditional student's attention to learning itself to focus on students' real life. As a result, guide students' feelings and experience the beauty of social life and enhance students' sense of survival. The art colleges and universities realize the organic link between the social subject and the learning subject through innovative entrepreneurship education, and realize the goal of cultivating all employees at the value level. 
From the realization of profession education in art colleges, the active and conscious participation and support of professional education for innovative entrepreneurship education helps to discover new problems and new situations in art practice, which provides the new perspective for professional education. Society and economy have improved the fresh activity and vividness of professional education, promoted the scientific research strength of art colleges into real productivity, and promoted the development of regional cultural undertakings.

From the cultivation of innovative entrepreneurship, profession education of art colleges plays a critical role. The innovative creation ability is the result of the balanced development and mutual cooperation of the left and right brain functions. The profession education of art colleges meets the development needs of people's spirit and culture, perfects the personality, enters the all-round development, and promotes the balanced development of the left and right brains, which helps stimulate students' innovative thinking and innovative creativity.

From educational goals, the goal of innovative entrepreneurship education is basically complied with the profession education goals of art colleges. The goal of innovative entrepreneurship education is to stimulate students' awareness of innovative entrepreneurship, to enhance students' ability of innovative entrepreneurship, and thus cultivate students' entrepreneurial spirit, which enables students to be independent and creative, and effectively and rationally integrate resources to realize the fulfillment of entrepreneurial projects. The goal of profession education in art colleges is to cultivate students' creative independent personality and self-transcendence awareness. Both profession art colleges and comprehensive college art design colleges should emphasize the dialectical relationship between the process value of art education and the ultimate value of talent cultivation, so as to cultivate artists and professional artists with independent personality and intelligence. Therefore, the role of profession education in art colleges is not only to produce works and talents, but to cultivate composite talents with aesthetic literacy and value pursuit. The ultimate goal is the comprehensive development of students, which are not the goal of innovative entrepreneurship education. Make a difference.

\section{The coupling relationship between innovative entrepreneurship education and art profession education}

The word coupling was the earliest used to describe a physical phenomenon which means the phenomenon that two or more systems or forms of motion interact, affect each other, and finally unite organically. The innovative entrepreneurship education and art profession education interact. They own both local features and the overall appearance, which is an obvious coupling relationship.

The purpose of education is to teach knowledge. The innovative entrepreneurship education put more emphasis on the practical experience while teaching the innovative entrepreneurship knowledge Art education focuses more on theoretical study while teaching profession knowledge. The innovative entrepreneurship education is to examine and apply the profession knowledge in practice learned from art colleges, to impose the sublimation of the art profession knowledge and the social value of professional education. Therefore, it is of importance to research the coupling relationship between both.

What is taught by the innovative entrepreneurship education and art education teach is different fields of knowledge. In order to better research on the knowledge in different fields, this knowledge should be divided into different modules. For example, the innovative entrepreneurial knowledge and profession knowledge is modularized. These complex knowledge systems are decomposed into modules and interwoven with each other to form into a larger system. Yet the modular knowledge itself is an independent sub-knowledge system, and also an open sub-knowledge system, which must coordinate with other knowledge modules to form a larger knowledge fields. 
As far as the knowledge module itself is concerned, it is an independent unit that exists in external connections. To improve the knowledge module itself, it is necessary to pay attention to the internal knowledge module and also to the relationship between knowledge modules to realize the synergistic relationship. In view of this, the coupling of innovative entrepreneurial knowledge and art professional knowledge has possibility and reality, which is also the objective demand of their respective development and evolution. The coupling of innovative entrepreneurial knowledge and profession knowledge is more conducive to the improvement of their respective knowledge at the sub-unit level and multi-dimensional level. The deep research on the coupling of different knowledge modules will be more conducive to the effective functioning of the overall knowledge system.

The knowledge module owns the integrity and the independence. To ensure that different knowledge modules do not influence each other, two contradictions need handling: Firstly, different knowledge modules must be coupling in the certain form, otherwise, they cannot be effectively combined; secondly, the relative independence between the knowledge modules is guaranteed, otherwise, the function of the knowledge module itself cannot be recovered. Based on this, it is possible to take a theoretical approach between focusing knowledge elements, namely loose this coupling. Carl Wick defined loose coupling, that is, when the overall hierarchical organizational performance covers up some local features, the system appears to the closely coupled; when some local features do not reflect the overall characteristics, the system is in an uncoupling state. The loose coupling is suitable when the overall feature and some local features co-exist, and the overall performance is not out of control due to the local functional scattering. The loose coupling theory is also applicable to cross-field combinations such as innovative entrepreneurship education and art profession education.

\section{The construction of coupling model of the innovative entrepreneurship education and art profession education}

The loose coupling theory provides a research method for cross-field and cross-knowledge systems. However, only relying on the knowledge combination cannot bring the actual social benefits, and must also consider the capability problems. The innovative entrepreneurship education is classified into innovative entrepreneurial knowledge and innovative entrepreneurship ability. Similarly, art professional education is classified into art profession knowledge and professional practice ability. Based on this, the coupling conceptual model of the two can be designed.

\subsection{Conceptual model}

Innovative entrepreneurial knowledge and art expertise are scattered into many courses that are composed of independent and interconnected knowledge modules, so are skill practices. As shown in Figure 1, the innovative entrepreneurial knowledge module includes many disciplinary knowledge fields, such as marketing, modern enterprise management, business administration, and economic law. The corresponding art profession knowledge modules include cross-fields knowledge such as art market, art management, art economics and arts. The final coupling result is the promotion of innovative entrepreneurial knowledge as a general module of the art profession education. The practice of innovative entrepreneurship will match the general knowledge of marketing, business management, business administration, economic law and industry development to propose a practical and effective solution. For the art entrepreneurship projects of art colleges, the cultural and creative companies focus on flexible management, the education and cultivation companies focus on refined management, and the art technological companies focus on high efficiency and practicality. In a word, all innovative entrepreneurial behaviors can only continue to 
develop in a healthy and sustainable manner only by the management role and the development of art.

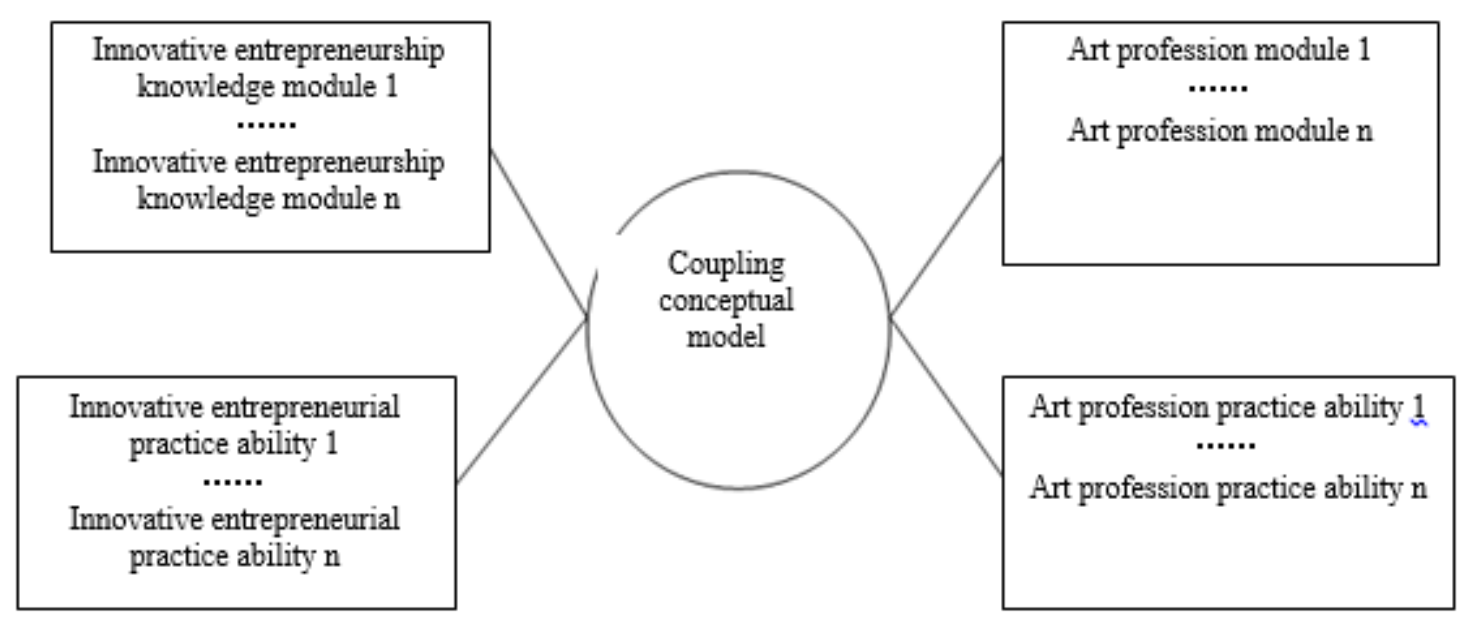

Figure 1 Coupling conceptual model of innovative entrepreneurship education and art profession education

\subsection{The coupling form}

The knowledge module and practice module of art profession education are relatively complete and stable, and the coupling of innovative entrepreneurship education and art profession education. Its core lies in the overall process of innovative entrepreneurship education throughout the art profession education. Therefore, it is necessary to construct the formal matrix of the loose coupling from 2D, namely, the completeness of the innovative entrepreneurial knowledge structure and the independence of the knowledge module, shown as Table 1.

Table 1 Coupling Formal Matrix of Innovative Entrepreneurship Education and Art Profession Education

\begin{tabular}{|c|c|c|}
\hline $\begin{array}{c}\text { High integrity of } \\
\text { innovative } \\
\text { entrepreneurial } \\
\text { knowledge }\end{array}$ & $\begin{array}{c}\text { The independence of low modules } \\
\text { I Tightly coupling: innovative } \\
\text { Entreneurship courses of the } \\
\text { overall independence }\end{array}$ & $\begin{array}{c}\text { The independence of high modules } \\
\text { entrepreneurial knowledge integrated } \\
\text { into the art courses }\end{array}$ \\
\hline $\begin{array}{c}\text { Low integrity of } \\
\text { innovative } \\
\text { entrepreneurial } \\
\text { knowledge }\end{array}$ & $\begin{array}{c}\text { III Non-coupling: No innovative } \\
\text { entrepreneurship course }\end{array}$ & $\begin{array}{c}\text { IV Discrete non-coupling: innovative } \\
\text { entrepreneurship knowledge } \\
\text { throughout art profession education } \\
\text { in the lecture form like Salons }\end{array}$ \\
\hline
\end{tabular}

In the 1st quadrant, innovative entrepreneurial knowledge has more integrity and the low independence of knowledge modules. Innovative entrepreneurial knowledge is only the overall components. The innovative entrepreneurial knowledge modules are closely related, but there is no connection with the art profession knowledge module. The innovative entrepreneurial knowledge is relatively independent in the art profession teaching.

In the 4th quadrant, the innovative entrepreneurial knowledge has the less integrity and the higher independence of knowledge modules. At this moment, there is no coupling relationship between the two knowledge modules. Innovative entrepreneurial knowledge and art profession are relatively independent, and there is no interaction between both. Based on this, successful off-campus people or outstanding entrepreneurs can be selected to deliver lectures, salons, 
workshops to enhance the coupling viscosity. These successful experiences have interdisciplinary referential effect. On this basis, focus on how to build the close relationship between the innovative entrepreneurial knowledge and the art profession.

In the 3rd quadrant, innovative entrepreneurial knowledge and art profession knowledge have neither completeness nor independence, that is, there is no innovative entrepreneurship education in art profession education. Obviously, this is beyond the range of our research.

In the 2nd quadrant, the innovative entrepreneurial knowledge owns a higher overall level and the higher independence of the knowledge module. The overall features of innovative entrepreneurship and the local features of the knowledge module co-exist. Therefore, it is necessary to perform the integrated construct of the innovative entrepreneurship knowledge module and the art profession knowledge module, and also should fully consider the match between the innovative entrepreneurial knowledge module and the art profession knowledge module.

\section{Acknowledgement}

Project information: This object belongs to the research project of humanities and social sciences of Xi'an Academy of Fine Arts (Project No.: 2018XK034)

\section{References}

[1] The Orientation of Chinese Education in the 21st Century [M]. Cai Keyong. Guangzhou: Guangdong Higher Education Press, 2004.

[2] Entrepreneurship Education [M]. Peng Gang. Nanjing: Jiangsu Education Press, 1995.

[3] The Research on College Students' Entrepreneurship Education [M]. Gao Wenbing. Shanghai: Fudan University Press, 2012.

[4] The Exploration and Discussion on Entrepreneurial Education Mode Based on College Students' Innovative Entrepreneurship Ability Cultivation [J]. Li Yu. Journal of Hubei University of Economics (Humanities and Social Sciences Edition), 2010 (10).

[5] The Analysis of College Students Entrepreneurship and their Entrepreneurship Education [J]. Gao Hong, Bai Leilei. Shanghai Management Science, 2012 (12).

[6] W.K.C.Guthric, A History of Greek philosophy, Vol. II. London: Cambridge University Press[M].Cicero. on the Good Life, translated by Michael Grant, Penguin Books, 1979 